\title{
Oxidative damage of DNA in subjects occupationally exposed to lead
}

\author{
Natalia Pawlas ${ }^{1,2, A-D, F}$, Elżbieta Olewińska ${ }^{1, A-D}$, Iwona Markiewicz-Górka ${ }^{3, B-D}$, Agnieszka Kozłowska ${ }^{1, B, C}$, \\ Lidia Januszewska ${ }^{3, B}$, Thomas Lundh ${ }^{4, B}$, Ewa Januszewska, ${ }^{5, D}$, Krystyna Pawlas ${ }^{1,3, B, E, F}$ \\ ${ }^{1}$ Institute of Occupational Medicine and Enviromental Health, Sosnowiec, Poland \\ ${ }^{2}$ Department of Pharmacology, Medical University of Silesia, School of Medicine with the Division of Dentistry, Zabrze, Poland \\ ${ }^{3}$ Department of Hygiene, Wroclaw Medical University, Poland \\ ${ }^{4}$ Division of Occupational and Environmental Medicine, University Hospital, Lund, Sweden \\ ${ }^{5}$ Cantonal Hospital Bruderholz, University of Basle, Switzerland \\ A - research concept and design; B - collection and/or assembly of data; $C$ - data analysis and interpretation; \\ $D$ - writing the article; $E$ - critical revision of the article; $F$ - final approval of article
}

\section{Address for correspondence \\ Natalia Pawlas \\ E-mail:n-pawlas@wp.pl}

\section{Funding sources}

This study was supported by Polish Ministry of Science, the Institute of Occupational Medicine and Environmental Health, the European Union (EU; FP6; PHIME; F00D-CT-2006-016253. The paper reflects only the authors' views; the $\mathrm{EU}$ is not liable for any use that may be made of the information).

\section{Conflict of interest}

None declared

Received on December 14, 2015

Revised on June 2, 2016

Accepted on August 17, 2016

\begin{abstract}
Background. Exposure to lead (Pb) in environmental and occupational settings continues to be a serious public health problem and may pose an elevated risk of genetic damage.

Objectives. The aim of this study was to assess the level of oxidative stress and DNA damage in subjects occupationally exposed to lead.
\end{abstract}

Material and methods. We studied a population of 78 male workers exposed to lead in a lead and zinc smelter and battery recycling plant and 38 men from a control group. Blood lead levels were detected by graphite furnace atomic absorption spectrophotometry and plasma lead levels by inductively coupled plasma-mass spectrometry. The following assays were performed to assess the DNA damage and oxidative stress: comet assay, determination of 8-hydroxy-2'-deoxyguanosine (8-OHdG), lipid peroxidation and total antioxidant status (TAS).

Results. The mean concentration of lead in the blood of the exposed group was $392 \pm 103 \mu \mathrm{g} / \mathrm{L}$ and was significantly higher than in the control group $(30.3 \pm 29.4 \mu \mathrm{g} / \mathrm{L}, \mathrm{p}<0.0001)$. Oxidative DNA damages measured by comet assay showed no significant differences between populations. The concentration of 8-OHdG was about twice as high as in the control group. We found a significant positive correlation between the level of biomarkers of lead exposure [lead in blood, lead in plasma, zinc protoporphyrin (ZPP)] and urine concentration of 8-OHdG. The level of oxidative damage of DNA was positively correlated with the level of lipid peroxidation (TBARS) and negatively with total anti-oxidative status (TAS).

Conclusions. Our study suggests that occupational exposure causes an increase in oxidative damage to DNA, even in subjects with relatively short length of service (average length of about 10 years). 8- $0 \mathrm{HdG}$ concentration in the urine proved to be a sensitive and non-invasive marker of lead induced genotoxic damage.

Key words: oxidative stress, lead exposure, DNA damage, comet assay, 8-hydroxy-2'-deoxyguanosine

DOI

10.17219/acem/64682

Copyright

Copyright by Author(s)

This is an article distributed under the terms of the

Creative Commons Attribution Non-Commercial License

(http://creativecommons.org/licenses/by-nc-nd/4.0/) 
Exposure to lead $(\mathrm{Pb})$ in the environmental and occupational settings continues to be a serious public health problem. Pb causes a number of adverse effects on many systems of the body like hematopoietic, renal, hepatic, bone, nervous, cardiovascular and reproductive systems. ${ }^{1}$ Exposure to $\mathrm{Pb}$ may pose an elevated risk of genetic damage. Subjects occupationally exposed to lead compounds have an increased risk of cancer, lung and gastric in particular. ${ }^{2,3}$

One of the recognized mechanisms of lead toxicity is the induction of oxidative stress. Excessive generation of ROS (Reactive Oxygen Species) is caused by the inhibition of $\delta$-ALAD ( $\delta$-aminolevulinic acid dehydratase) by lead. As a result of this, there is an increased accumulation of $\delta$-ALA (aminolevulinic acid), which undergoes enolization and auto-oxidation and generates hydrogen peroxide and superoxide radical, and also interacts with oxyhemoglobin. The final oxidation product of $\delta$-ALA, 4,5-dioxovaleric acid, is an effective alkylating agent of the guanine in DNA. The generation of potentially genotoxic compound is a possible mechanism for the metal-dependent DNA carcinogenicity of lead. ${ }^{1,4}$ The lead-induced generation of ROS results in the attack of polyunsaturated fatty acid residues of phospholipids, which are extremely sensitive to oxidation. The main product of peroxidation process is malondialdehyde (MDA). MDA can react with DNA bases (G, A and C) and form adducts. M1G (pyrimido [1,2-a] purin-10(3H)-one), a major endogenous DNA adduct in humans is mutagenic and may lead to the formation of DNA-DNA crosslinks or DNA-protein crosslinks. ${ }^{5}$ Significantly elevated levels of lipid peroxide in the plasma, even among workers exposed to low concentrations of lead, has been observed. ${ }^{6}$

Most oxidative DNA damage is caused by very reactive hydroxyl radical, which is known to react with all components of the DNA molecule. The effects of oxidative DNA damage are GC/TA transversions, single strand breaks, double strand breaks, generation of apurinic/apyrimidinic sites and DNA-DNA crosslinks. This kind of damages can result in the arrest or induction of transcription, induction of signal transduction pathways, replication errors and genomic instability, all of which are associated with carcinogenesis and mutagenesis. ${ }^{5,6}$

Comet assay is a simple, rapid and sensitive method for measuring DNA damage, such as single-strand DNA breaks (SSB), double-strand DNA breaks (DSB), alkali labile sites (apurinic/apyrimidic sites), crosslinks and incomplete DNA repair sites. ${ }^{7,8}$ A modified version of comet assay with an addition of formamidopyrimidine glycosilase (FPG) can be used for the detection of DNA damage induced by reactive oxygen species. ${ }^{9,10}$

Hydroxyl radical reacts with all the nucleobases of DNA, but most frequently causes damage to guanine. This leads to the formation of C8-hydroxyguanine
(8-OHGua) or deoxyguanosine (8-hydroxy-2'-deoxyguanosine, 8-OHdG), its nucleoside form. The formation of 8-OHdG is caused by the weakening of the antioxidant system of the organism, as well as the imprecise repair of the damaged nucleic acid. 8-OHdG is promutagenic, and thus may be used as a potential biomarker of increased risk of carcinogenesis. ${ }^{11}$

Detection of those early, adverse changes in cells caused by exposure to lead allows us to undertake prevention measures reducing the health risks for employees. For this reason, the present study was carried out to assess the level of oxidative stress, in markers of oxidative DNA damage (urinary 8-OHdG levels, comet assay) in subjects occupationally exposed to lead.

Inhibition of ferrochelatase activity by lead prevents the incorporation of iron into protoporphyrin and the formation of heme. This leads to binding of zinc ( $\mathrm{Zn})$ and the production of zinc protoporphyrin (ZPP). An increase in ZPP production has been recognized to be an early biological effect of lead exposure and has been frequently used in health effects monitoring for lead exposure. .,4,12 $^{2}$ Concentration of lead in blood is a result of both current and long term exposure. ${ }^{13}$

Another aim of our study was to analyze the correlation between the $\mathrm{Pb}$ exposure markers (lead in blood (B-Pb), ZPP) and markers of oxidative stress, DNA damage and level of antioxidative defence (total antioxidative status, TAS).

\section{Subjects and methods}

\section{Study population}

We studied a population of 78 male workers (aged from 20 to 62 years, mean age $36.4 \pm 8.6$ years) employed in lead and zinc smelter and battery recycling plant, exposed to lead. They were exposed to lead for $10.5 \pm 8.3$ years $(0.8-$ 35 years). The control group consisted of 38 men (aged from 19 to 61 years, mean age $35.0 \pm 10.4$ years) with no history of occupational exposure to lead, who were working for $11.6 \pm 9.0$ years (0.5-38 years). Only environmental exposure to lead occurred in the control group. Based upon questionnaire data, neither the exposed nor control group suffered from any acute or chronic disease, nor were alcohol addicted.

We used urine and blood samples collected in PHIME project (FOOD-CT-2006-016253) in 2009-2010. Blood was collected by venipuncture into sterile tubes containing either lithium heparin or ethylenediamine-tetraacetic acid (EDTA) solution as an anticoagulant. Blood samples were stored at $-20^{\circ} \mathrm{C}$ and urine at $-80^{\circ} \mathrm{C}$ until required for analysis. The protocol for this project has been approved by Bioethics Committee at Institute of Occupational and Environmental Health. All subjects gave informed consent. 


\section{Lead intoxication parameters}

$\mathrm{B}-\mathrm{Pb}$ levels were detected by graphite furnace atomic absorption spectrophotometry using Perkin-Elmer 4100ZL instrument. The laboratory participates in internal and inter-laboratorial proficiency tests (CDC in Atlanta, USA). ZPP levels were measured in whole blood using a haematofluorometer. The concentrations of $\mathrm{B}-\mathrm{Pb}$ were quantified as $\mu \mathrm{g} / \mathrm{l}$ and $\mathrm{ZPP}$ as $\mu \mathrm{g} / \mathrm{g} \mathrm{Hb}$.

The concentrations of lead in plasma $(\mathrm{P}-\mathrm{Pb})$ were determined in samples diluted 5 times with an alkaline solution, according to Barany et al., by inductively coupled plasma-mass spectrometry (ICP-MS; Thermo X7, Thermo Elemental, Winsford, UK). ${ }^{14}$ The detection limit, calculated as 3 times the standard deviation (SD) of the blank, was $0.06 \mu \mathrm{g} / \mathrm{L}$. All analyzed samples were prepared in duplicate and the method imprecision (calculated as the coefficients of variations in measurements of duplicate preparations) was $2.5 \%$. To ensure analytical accuracy, quality control samples were analyzed along with the collected samples. The results obtained (mean $\pm \mathrm{SD}$ ) were $0.99 \pm 0.08 \mu \mathrm{g} / \mathrm{L}(\mathrm{n}=9)$ vs recommended $1.02 \mu \mathrm{g} / \mathrm{L}$ (Seronorm Elements Serum, lot 0903106; SERO AS, Billingstad, Norway) and $9.3 \pm 0.46 \mu \mathrm{g} / \mathrm{L}(\mathrm{n}=9)$ vs recommended 8.2 \pm 0.83 (Centre de Toxicologie du Quebec, International Comparison Program, Quebec, Canada; lot QMEQAS068-06).

\section{Comet assay method}

The DNA damage was analyzed in whole blood using alkaline comet assay according to the method by Singh et al. with some modification and FPG-modified comet assay, as previously described. ${ }^{15,16}$ Briefly, $40 \mu \mathrm{L}$ of whole blood in $1 \%$ low melting point agarose (Sigma) was placed on a microscope slide that had been precoated with $0.5 \%$ normal melting point agarose (Sigma). Coverslips were placed on the gels, and the slides with coverslips were put on ice. Then coverslips were removed and the slides were submersed in lysis solution $\left(2.5 \mathrm{~mol} \mathrm{~L}^{-1} \mathrm{NaCl}, 10 \mathrm{mmol} \mathrm{L}{ }^{-1}\right.$ EDTA, $1 \mathrm{mmol} \mathrm{L}^{-1}$ Tris, $1 \%$ Tritron $\mathrm{X}-100, \mathrm{pH}=10$ ) at $4^{\circ} \mathrm{C}$ in the dark. After 1 hour, the slides were washed 3 times with enzyme reaction buffer $\left(4 \mathrm{mmol} \mathrm{L} \mathrm{L}^{-1}\right.$ Hepes, $0.1 \mathrm{~mol} \mathrm{~L}^{-1}$ $\mathrm{KCl}, 0.5 \mathrm{mmol} \mathrm{L}^{-1} \mathrm{EDTA}, 0.2 \mathrm{mg} / \mathrm{mL} \mathrm{BSA}$ ) at $4^{\circ} \mathrm{C}$ for $5 \mathrm{~min}$ each. Then slides were treated with $70 \mu \mathrm{L}$ of FPG solution (New England Biolabs) or buffer alone as control. The enzyme was diluted right before use. The slides were placed in a humid chamber at $37^{\circ} \mathrm{C}$ for $30 \mathrm{~min}$ and then washed with cold PBS solution. Afterwards, the slides were placed in a horizontal electrophoresis tank filled with electrophoresis buffer $\left(30 \mathrm{mmol} \mathrm{L}^{-1} \mathrm{NaOH}, 1 \mathrm{mmol} \mathrm{L}^{-1}\right.$ EDTA) for $40 \mathrm{~min}$ at $4^{\circ} \mathrm{C}$ to DNA unwinding and denaturation. Electrophoresis was carried out for $30 \mathrm{~min}$ at $1.2 \mathrm{~V} / \mathrm{cm}$. In order to reduce light-induced DNA damage, all steps were performed under red light. Af- ter electrophoresis, the slides were washed 3 times with a neutralization buffer $\left(0.4 \mathrm{~mol} \mathrm{~L}^{-1}\right.$ Tris- $\left.\mathrm{HCl}, \mathrm{pH}=7.5\right)$, dried and stained with DAPI (4,6-diamidino-2-phenylindole) solution $(1 \mu \mathrm{g} / \mathrm{mL})$. The slides were stored in a closed humid chamber at $4^{\circ} \mathrm{C}$ for $20 \mathrm{~h}$. Slides were prepared in duplicate per person and analyzed by image analysis system Comet v. 5.5 (Kinetic Imaging Ltd., Liverpool, UK). 75 cells were calculated per 1 person ( 2 slides). To quantify DNA damage, the following comet parameters evaluated the percentage of DNA in the tail (relative fluorescence intensity of tail; TI), tail length (distance from head center to the end of the tail; in $\mathrm{m}$ ) and tail moment (TM), which was calculated as tail length $\times$ percentage of DNA in tail (in arbitrary units). The control slides (no enzyme treatment) provided an estimate of the background of DNA strand breaks. The enzyme-treated slides revealed strand breaks and oxidized bases (total DNA damage). Differences in the tail length $(\Delta \mathrm{TL})$, tail intensity $(\Delta \mathrm{TI})$, and tail moment $(\Delta \mathrm{TM})$, between samples obtained with standard alkaline comet assay and FPG-modified comet assay were considered as oxidative DNA damage.

\section{DNA damage in urine}

Detection of 8-OHdG was performed using ready-touse ELISA-based assay (Cat. RSCN213100R, BioVendor) according to the manufacturer's instructions. Samples of urine and 8-OHdG standards were added to a 96-well plate which has been precoated with 8-OHdG. Then, the 8-OHdG monoclonal antibody was added and the plate was incubated at $37^{\circ} \mathrm{C}$ for $1 \mathrm{~h}$. Next, the plate was washed and incubated with secondary antibody labeled with horseradish peroxidase at $37^{\circ} \mathrm{C}$ for $1 \mathrm{~h}$. The plate was washed thrice and substrate solution was added and incubated for $15 \mathrm{~min}$ at room temperature before a stop solution (1M phosphoric acid) was added. Spectrophotometric readings were obtained at $450 \mathrm{~nm}$ by using $\mathrm{BIO}-$ TEK PowerWave XS microplate reader (BIO-TEK Instruments). The concentration of $8-\mathrm{OHdG}$ in urine was determined using a standard curve. The level of 8-OHdG was expressed as ng/g creatinine.

\section{Determination of lipid peroxidation}

Urine levels of lipid peroxides were determined as TBARS using Cayman TBARS Assay Kit (Cat. 10009055 Cayman Chemical, USA). The MDA-TBA adduct formed by the reaction of MDA and TBA under high temperature $\left(90-100^{\circ} \mathrm{C}\right)$ and acidic conditions were measured colorimetrically at 530-540 nm using the BIO-TEK PowerWave XS microplate reader (BIO-TEK Instruments). The concentration of MDA was determined using an MDA standard curve. Results were expressed as $\mu \mathrm{mol}$ MDA per liter and $\mu$ mol MDA per gram of creatinine. Typically, normal human urine has a lipid peroxide level of $0.8-2.0 \mu \mathrm{mol} / \mathrm{g}$ creatinine. 


\section{Total antioxidant status (TAS)}

TAS was measured in urine using the Antioxidant Assay Kit (Cat. 709001, Cayman Chemical) following the manufacturer's instruction. This assay relies on the ability of the antioxidants in the sample to inhibit the oxidation of 2,2-azino-di- [3-ethylbenzthiazoline sulphonate] (ABTS) to ABTS+ radical by metmyoglobin. The amount of ABTS + was monitored by reading the absorbance at $750 \mathrm{~nm}$. The antioxidants in the sample caused the suppression of the absorbance to a degree which was proportional to their concentration. The capacity of the antioxidants in the sample to prevent ABTS oxidation was compared with that of Trolox, a water-soluble tocopherol analogue and was quantified as milimolar Trolox equivalents. The plate reader used was BIO-TEK PowerWave XS (BIO-TEK Instruments).

\section{Statistical analysis}

The STATISTICA v. 9.PL was used for data analysis. The Shapiro-Wilks test was used to verify normality. The significance of difference between the exposed and control group was determined using the Mann-Whitney $U$ test as the data distribution was non-parametric. Spearman's non-parametric correlation was used to find out the correlation between study parameters. The probability values of $\mathrm{p}<0.05$ were considered significant.

\section{Results}

Table 1 presents the characteristics of the exposed and control groups. No statistical differences in age and body weight were found between the groups. The percentage of smokers was evenly distributed within both groups.

The mean concentration of lead in blood in exposed group was $392 \pm 103 \mu \mathrm{g} / \mathrm{L}$ and was significantly higher than in control group $(30.3 \pm 29.4 \mu \mathrm{g} / \mathrm{L}, \mathrm{p}<0.0001)$.

The differences between study groups were also significant ( $\mathrm{p}<0.001$ ) according to lead level in plasma and ZPP, which were higher among occupationally exposed subjects (Table 2). The results of biomarkers of oxidative stress demonstrated that subjects exposed to lead had a lower level of antioxidant status and higher levels of TBARS and 8-OHdG, but only the latter was significantly different compared to control group ( $p=0.01$ ).

Oxidative DNA damages measured by FPG-modified comet assay showed no significant differences between populations.

Correlations between the studied parameters are shown in Table 3. Lead intoxication parameters significantly correlated with each other. We found a positive correlation between biomarkers of lead exposure (B-Pb, $\mathrm{P}-\mathrm{Pb}, \mathrm{ZPP}$ ) and DNA damage in urine. The level of lipid peroxidation (TBARS) was found to be significantly cor-
Table 1. Characteristic of exposed and control groups

\begin{tabular}{|l|c|c|c|}
\hline \multicolumn{1}{|c|}{ Variable } & $\begin{array}{c}\text { Exposed group } \\
(\mathbf{n}=78)\end{array}$ & $\begin{array}{c}\text { Control group } \\
(\mathrm{n}=38)\end{array}$ & p-value \\
\hline Age (years) & $36.5 \pm 8.6$ & $35.0 \pm 10.4$ & ns \\
\hline $\begin{array}{l}\text { Weight (kg) } \\
\text { Years of exposure }\end{array}$ & $10.5 \pm 8.3 \pm 13.2$ & $85.2 \pm 15.5$ & ns \\
\hline $\begin{array}{l}\text { to lead } \\
\text { Smoking habit: } \\
\text { Yes } \\
\text { No }\end{array}$ & $26(33 \%)$ & - & - \\
\hline
\end{tabular}

Mean (SD) or n (\%); ns - non significant.

Table 2. Comparison of studied groups

\begin{tabular}{|c|c|c|c|}
\hline Variable & $\begin{array}{c}\text { Exposed } \\
\text { group }(n=78)\end{array}$ & $\begin{array}{l}\text { Control group } \\
\qquad(n=38)\end{array}$ & $p$-value \\
\hline $\mathrm{B}-\mathrm{Pb}(\mu \mathrm{g} / \mathrm{L})$ & $392 \pm 103$ & $30.3 \pm 29.4$ & $<0.001$ \\
\hline $\mathrm{P}-\mathrm{Pb}(\mu \mathrm{g} / \mathrm{L})$ & $1.53 \pm 0.66$ & $0.080 \pm 0.11$ & $<0.001$ \\
\hline $\mathrm{ZPP}(\mu \mathrm{g} / \mathrm{g} \mathrm{Hb})$ & $5.5 \pm 3.9$ & $2.05 \pm 0.92$ & $<0.001$ \\
\hline $\begin{array}{l}\text { 8-OHdG } \\
\text { (ng/g creatinine) }\end{array}$ & $41.5 \pm 36.8$ & $24.6 \pm 29.1$ & 0.01 \\
\hline $\begin{array}{l}\text { TAS } \\
\text { (mmol/ g creatinine) }\end{array}$ & $2.13 \pm 1.75$ & $2.57 \pm 2.18$ & ns \\
\hline $\begin{array}{l}\text { TBARS } \\
\text { ( } \mu \mathrm{mol} / \mathrm{g} \text { creatinine) }\end{array}$ & $6.74 \pm 6.20$ & $5.46 \pm 5.65$ & ns \\
\hline TI (\% DNA) & $14.1 \pm 8.8$ & $16.2 \pm 12.8$ & ns \\
\hline TM & $6.5 \pm 8.4$ & $10.2 \pm 15.7$ & ns \\
\hline $\mathrm{TL}(\mu \mathrm{m})$ & $28.4 \pm 13.5$ & $31.9 \pm 24.4$ & ns \\
\hline TI - FPG (\% DNA) & $66.1 \pm 13.8$ & $65.3 \pm 13.2$ & ns \\
\hline $\mathrm{TM}-\mathrm{FPG}$ & $42.2 \pm 12.9$ & $46.7 \pm 18.3$ & ns \\
\hline $\mathrm{TL}-\mathrm{FPG}(\mu \mathrm{m})$ & $59.5 \pm 10.5$ & $65.3 \pm 22.0$ & ns \\
\hline$\triangle \mathrm{TI}(\% \mathrm{DNA})$ & $52.0 \pm 15.9$ & $49.1 \pm 18.8$ & ns \\
\hline$\triangle T M$ & $35.7 \pm 14.3$ & $36.5 \pm 16.1$ & ns \\
\hline$\Delta \mathrm{TL}(\mu \mathrm{m})$ & $31.1 \pm 15.1$ & $33.4 \pm 15.6$ & ns \\
\hline
\end{tabular}

Mean (SD) or n (\%); ns - non significant; 8-OHdG - 8-hydroxy-2'-deoxyguanosine; $\triangle$ - change; B-Pb - blood lead level; FPG - formamidopyrimidine glycosilase assay modification; P-Pb - plasma lead level; TAS - total antioxidative status; TBARS - thiobarbituric acid reactive substances - lipid peroxidation; TI - tail intensity; TL - tail length; TM - tail movement; ZPP - zinc protoporhyrin.

related with oxidative DNA damage measured by comet assay. The negative correlations were observed between tail intensity, tail length, tail moment and TAS.

\section{Discussion}

A safe level of lead exposure is very hard to define because health risks associated with lead are found at even low doses. ${ }^{13}$ The permitted biological concentration of 
Table 3. Correlation between study parameters in studied population

\begin{tabular}{|c|c|c|c|c|c|c|}
\hline Variable & $\mathrm{B}-\mathrm{Pb}$ & $\mathrm{P}-\mathrm{Pb}$ & ZPP & 8-OHdG & TAS & TBARS \\
\hline $\mathrm{B}-\mathrm{Pb}$ & 1.00 & & & & & \\
\hline $\mathrm{P}-\mathrm{Pb}$ & $0.90^{* * *}$ & 1.00 & & & & \\
\hline ZPP & $0.64^{* * *}$ & $0.71^{* * *}$ & 1.00 & & & \\
\hline 8-OHdG & $0.19^{*}$ & $0.20^{*}$ & $0.27^{* *}$ & 1.00 & & \\
\hline TAS & ns & ns & ns & ns & 1.00 & \\
\hline TBARS & ns & ns & ns & $0.43^{* * *}$ & ns & 1.00 \\
\hline $\mathrm{TI}$ & ns & ns & ns & ns & $0.18^{*}$ & ns \\
\hline TM & ns & ns & ns & ns & $0.20^{*}$ & ns \\
\hline TL & ns & ns & ns & ns & ns & ns \\
\hline $\mathrm{TI}-\mathrm{FPG}$ & ns & ns & $0.19^{*}$ & ns & ns & $0.29 * *$ \\
\hline TM - FPG & ns & ns & ns & ns & ns & $0.19^{*}$ \\
\hline$T L-F P G$ & ns & ns & ns & ns & ns & ns \\
\hline$\Delta \mathrm{TI}$ & ns & ns & ns & ns & $-0.21^{*}$ & $0.26^{* *}$ \\
\hline$\triangle \mathrm{TM}$ & ns & ns & ns & ns & $-0.23^{*}$ & $0.22^{*}$ \\
\hline$\Delta T L$ & ns & ns & ns & ns & $-0.24^{* *}$ & ns \\
\hline
\end{tabular}

Spearman's R values ${ }^{*} \mathrm{p}<0.05 ;{ }^{* *} \mathrm{p}<0.01 ;{ }^{* * *} \mathrm{p}<0.001$, ns - non significant; 8-OHdG - 8-hydroxy-2'-deoxyguanosine; $\triangle$ - change; B-Pb - blood lead level; FPG - formamidopyrimidine glycosilase assay modification; P-Pb - plasma lead level; TAS - total antioxidative status; TBARS - thiobarbituric acid reactive substances - lipid peroxidation; TI - tail intensity; TL - tail length; TM - tail movement; ZPP - zinc protoporhyrin.

lead in blood in Poland, according to the regulation of Ministry of Health, is $500 \mu \mathrm{g} / \mathrm{L}$ of blood and $300 \mu \mathrm{g} / \mathrm{L}$ of blood for women under 45 years of age. In other countries, like Germany, those levels are lower, at $400 \mu \mathrm{g} / \mathrm{L}$ for men and $100 \mu \mathrm{g} / \mathrm{L}$ for women. Researchers suggests a negative effect of $\mathrm{Pb}$ on kidneys, nervous, hematopoietic and cardiovascular systems even at lower levels; therefore, organizations such as ACGIH (American Conference Governmental and Industrial Hygienists) and SCOEL (Scientific Committee on Occupational Exposure Limit Values) recommend reducing the permitted concentration of $\mathrm{Pb}$ in blood to $300 \mu \mathrm{g} / \mathrm{L}^{1}$

Vaglenov et al. were measuring the levels of DNA damage in peripheral blood lymphocytes of subjects exposed to lead, based on increases in frequency of binuclear cells with micronuclei (BNMN). ${ }^{17}$ They observed that even at low lead concentrations B-Pb 1.2-1.9 $\mu \mathrm{mol} \mathrm{L}{ }^{-1}(\mathrm{~B}-\mathrm{Pb}$ 248-393 $\mu \mathrm{g} / \mathrm{L})$, where no clinical changes are seen, an increased risk of genetic material damage in the cells occurs. The average concentration of lead in the blood of subjects analyzed by us was within the upper limit suggested by Vaglenov et al. and was equal to $392 \pm 103 \mu \mathrm{g} / \mathrm{L} .{ }^{17}$ It was, however, 13 times higher than that of the control group. The concentration of ZPP and 8-OHdG was about twice as high as in the control group. We found also a positive correlation between lead exposure markers $(\mathrm{B}-\mathrm{Pb}, \mathrm{P}-\mathrm{Pb}$ and ZPP) and the level of oxidative damage of DNA in urine (concentration of $8-\mathrm{OHdG}$ ). Our results are in line with earlier findings that occupational exposure even to low levels of lead as well as to levels not exceeding the permissible levels increases the risk of genetic damage. ${ }^{17,18}$

We have observed also an inverse relationship between oxidative damage, measured as change in tail intensity, tail length, tail moment between FPG modification and standard comet assay, and antioxidative potential (TAS) in serum, and positive correlation between level of lipid peroxidation (TBARS) and levels of DNA damage (measured based on both comet method as well as based on 8-OHdG levels in urine). Those results confirm the relationship between a weakened antioxidative defence and oxidative stress induced by various factors, including $\mathrm{Pb}$, and the effects of genotoxic, observed also by other authors. ${ }^{5,19}$

Genotoxic effects may be modulated by many factors affecting studied subjects, such as cumulated exposure to lead, genetic predispositions, health, nutrition, smoking, drinking alcohol and other present in the environment, causing damage to the genetic material. ${ }^{20}$

Polymorphic genes taking part in pollution metabolism or in DNA repair processes may control the degree of damage caused by exposure to genotoxic factors and increase the risk of cancer and other diseases. ${ }^{21}$ Coelho et al. 
observed significantly increased levels of DNA damage biomarkers in people environmentally and occupationally exposed to metals/metaloids. ${ }^{21}$ Those effects were correlated with internal doses of exposure and were more common in sensitive genotypes. Gene polymorphisms may influence the rate and efficiency of recovery and thus shape the individual sensitivity to $\mathrm{Pb}$ in the environment.

The choice of the method of measurement used to assess the level of DNA damage is equally important. The comet method gives the possibility of detecting DNA damage at the single cell level, identifying DNA breaks and chemical and enzymatic modifications that can be converted into breakage of DNA or chromatids. The comet assay can analyze any tissue which can provide cell suspension. ${ }^{7,10}$

The comet assay has been used in numerous studies to evaluate genotoxicity associated with lead exposure. ${ }^{16,22-26}$ Most of them reported increased levels of DNA damage measured by comet assay parameters in exposed workers with regard to controls. In our study, the comet assay did not show a significantly higher incidence of oxidative DNA damage in exposed workers compared to the control group. Although the tail length was widely used in different biomonitoring studies, it has been criticized due to the sensitivity to the background and threshold setting of the image analysis program. ${ }^{9,10}$ The divergences can also be explained by differences in the methodology, the characteristics of the populations studied and different biological material used for analysis. We have performed our assay in whole blood, while in the above-mentioned reports the damage was studied in isolated leukocytes.

Steinmetz-Beck et al. suggest a positive linear correlation between the concentration of lead in the blood and the values of comet parameters. ${ }^{27}$ We did not observe this relation; however, we found a positive correlation between $\mathrm{B}-\mathrm{Pb}$ and $8-\mathrm{OHdG}$ concentration in urine. In our study, the exposed group mainly consisted of young people with a rather short length of service and the $\mathrm{B}-\mathrm{Pb}$ was lower than in the group measured by Steinmetz-Beck and coauthors. The average time of exposure to lead was equal to $10.5 \pm 8.3$ years and the age $36.5 \pm 8.6$ years vs $19 \pm 7.1$ (length) and $46.7 \pm 8.6$ (age) respectively. Also, Olewińska et al. observed associations between B-Pb and DNA damage measured by comet assay but in their study the mean $\mathrm{B}-\mathrm{Pb}$ was higher $(457 \mu \mathrm{g} / \mathrm{L})$, the population was older (mean age 39.2 years) and the duration of exposure to lead was longer (14.2 years). ${ }^{16}$ The other possible explanation is that in most of the studies the isolated leukocytes were used for comet assay, while we used fresh whole blood. The advantage of using fresh whole blood is that the amount of blood which is used is $40 \mu \mathrm{L}$, while for the isolation of leukocytes a bigger volume is required. It is possible that the comet assay reflects the damage which can be repaired relatively quickly, especially in young, healthy people with efficient recovery mechanisms, while urinary 8-OHdG reflect the change more intractable to repair. Studies by Kim et al. also have indicated a posi- tive association between $\mathrm{Pb}$ exposure and oxidative DNA damage (measured as urine concentration of 8-OHdG) in relatively young and healthy cohort of workers exposed to high levels of metal-containing particulate matter. ${ }^{18}$

$\mathrm{B}-\mathrm{Pb}$ reflects to a greater extent the current rather than long-term exposure and as such does not show the cumulated levels of exposure to $\mathrm{Pb} \cdot{ }^{13}$ However, $\mathrm{Pb}$ concentration in blood increases with years of exposure. ${ }^{19}$ Occupational exposure to $\mathrm{Pb}$ is associated with decreased repair capacity of DNA..$^{28}$ The increase in comet parameters observed at higher $\mathrm{Pb}$ concentrations due to prolonged exposure can be associated with less efficient and more error-prone mechanisms of repair of DNA.

Other studies also have not found significant differences in the level of DNA damage measured by the comet method between the group exposed and the control one. In the study by García-Lestón et al., the average concentration of lead in the blood of subjects heavily exposed to lead (workers from chemical plants and producing rechargeable batteries) was $312 \pm 21 \mu \mathrm{g} / \mathrm{L}$, and in the control group (administrative staff) was about 9 times lower $(35.4 \pm 4.3 \mu \mathrm{g} / \mathrm{L})$; however, there are no differences in the values of the comet parameters between these groups. ${ }^{29}$ There was a significant increase in the frequency of mutations in the T-cell receptor (TCR -MF) in subjects exposed to $\mathrm{Pb}$ compared to control group. According to these authors, the changes detected in the TCR mutation assay are a result of an earlier long-term exposure taking place from several months to 2-3 years before the measurement, and the comet assay reflects the more recently formed damage, which is quickly repaired. Thus, the differences between the control group and the $\mathrm{Pb}$ exposed, assayed by comet method, are not always significant.

The urinary excretion of 8-OHdG has been used as a biomarker to assess the extent of repair of ROS-induced DNA damage in both the clinical and occupational setting. 8-OHdG forms a alkali pair with cytosine and adenine and increases the rate of spontaneous mutations incorporated into DNA. 8-OHdG is considered to be a useful marker of oxidative damage of DNA, increased risk of carcinogenesis and the development of degenerative diseases. ${ }^{11,18}$

In our study, 8-OHdG analysis in the urine was a more sensitive method of measuring genetic damage associated with occupational exposure to $\mathrm{Pb}$ compared to the comet method. As previously mentioned, 8-OHdG level in urine was significantly higher in $\mathrm{Pb}$ exposed subjects when compared to control subjects, and additionally this level positively correlated with the concentration of lead in plasma and the level of lipid peroxidation.

In summary, our study suggests that occupational exposure to $\mathrm{Pb}$ causes an increase in oxidative damage to DNA, which, in turn, increases the risk of carcinogenesis. These changes were observed in subjects with relatively short length of service (average length of about 10 years) and with significantly lower than the permissible limit 
of lead concentration in the blood. 8-OHdG concentration in the urine proved to be a sensitive and non-invasive marker of lead induced genotoxic damage.

\section{References}

1. Flora G, Gupta D, Tiwari A. Toxicity of lead: A review with recent updates. Interdiscip Toxicol. 2012;5:47-58.

2. Rousseau MC, Parent ME, Nadon L, Latreille B, Siemiatycki J. Occupational exposure to lead compounds and risk of cancer among men: A population-based case-control study. Am J Epidemiol. 2007;166:1005-1014.

3. Mushak P. Carcinogenic and genotoxic effects of lead in human populations. In book series: Trace metals and other contaminants in the environment. Lead and Public Health. Elsevier; 2011;10:635-670.

4. Patrick L. Lead toxicity, a review of the literature. Part 1: Exposure, evaluation, and treatment. Altern Med Rev J Clin Ther. 2006;11(1):2-22.

5. Valko M, Rhodes CJ, Moncol J, Izakovic M, Mazura M. Free radicals, metals and antioxidants in oxidative stress-induced cancer. Chem Biol Interact. 2006;160(1):1-40.

6. Mohammad IK, Mahdi AA, Raviraja A, Najmul I, Iqbal A, Thuppil V. Oxidative stress in painters exposed to low lead levels. Arh Hig Rada Toksikol. 2008;59(3):161-169.

7. Collins AR. The comet assay for DNA damage and repair: Principles, applications, and limitations. Mol Biotechnol. 2004;26(3):249-261.

8. Valverde $M$, Ostrosky-Wegman P, Rojas $E$, et al. The application of single cell gel electrophoresis or Comet assay to human monitoring studies. Salud Pública México. 1999;41(2):109-113.

9. Collins AR. The use of bacterial repair endonucleases in the comet assay. Methods Mol Biol. 2011:691;137-147.

10. Collins AR, Oscoz AA, Brunborg G, et al. The comet assay: Topical issues. Mutagenesis. 2008;23(3):143-151.

11. Valavanidis A, Vlachogianni T, Fiotakis C. 8-hydroxy-2'-deoxyguanosine (8-OHdG): A critical biomarker of oxidative stress and carcinogenesis. J Environ Sci Health C Environ Carcinog Ecotoxicol Rev. 2009;27:120-139.

12. Kasuba V, Rozgaj R, Milić M, et al. Evaluation of lead exposure in battery-manufacturing workers with focus on different biomarkers. J Appl Toxicol Jat. 2010;30(4):321-328.

13. Prüss-Üstün A, Fewtrell L, Landrigan PJ, Ayuso-Mateos JL. Lead exposure. In: Ezzati M, Lopez AD, Rodgers A, Murray CJL, eds. Comparative quantification of health risks: Global and regional burden of disease attributable to selected major risk factors. 1498, World Health Organization 2004, Geneva, Switzerland.

14. Barany E, Bergdahl I, Schütz A, Skerfving S, Oskarsson A. Inductively coupled plasma mass spectrometry for direct multi-element analysis of diluted human blood and serum. J Anal At Spectrom. 1997;12:1005-1009.
15. Singh NP, McCoy MT, Tice RR, Schneider EL. A simple technique for quantitation of low levels of DNA damage in individual cells. Exp Cell Res. 1988;75(1):184-191.

16. Olewińska E, Kasperczyk A, Kapka L, et al. Level of DNA damage in lead-exposed workers. Ann Agric Environ Med. 2010;17(2):231-36.

17. Vaglenov A, Creus A, Laltchev S, Petkova V, Pavlova S, Marcos R. Occupational exposure to lead and induction of genetic damage. Environ Health Perspect. 2001;109(3):295-298.

18. Kim JY, Mukherjee S, Ngo LC, Christiani DC. Urinary 8-hydroxy2'-deoxyguanosine as a biomarker of oxidative DNA damage in workers exposed to fine particulates. Environ Health Perspect. 2004;112(6):666-671.

19. Chinde S, Kumari M, Devi KR, et al. Assessment of genotoxic effects of lead in occupationally exposed workers. Environ Sci Pollut Res. 2014;21:11469-11480.

20. Battershill JM, Burnett K, Bull S. Factors affecting the incidence of genotoxicity biomarkers in peripheral blood lymphocytes: Impact on design of biomonitoring studies. Mutagenesis. 2008;23(6): 423-437.

21. Coelho P, García-Lestón J, Costa S, et al. Genotoxic effect of exposure to metal(loid)s. A molecular epidemiology survey of populations living and working in Panasqueira mine area, Portugal. Environ Int. 2013;60:163-170.

22. Kasuba V, Rozgaj R, Milić M, et al. Evaluation of lead exposure in battery-manufacturing workers with focus on different biomarkers. J App/ Toxicol. 2010;30:321-328.

23. Danadevi K, Rozati R, Saleha Banu B, Hanumanth Rao P, Grover P. DNA damage in workers exposed to lead using comet assay. Toxicology. 2003;187(2-3):183-93.

24. Valverde M, Rojas E. Environmental and occupational biomonitoring using the Comet assay. Mutat Res. 2009;681(1):93-109.

25. Kašuba V, Rozgaj R, Milić $M$, et al. Evaluation of genotoxic effects of lead in pottery-glaze workers using micronucleus assay, alkaline comet assay and DNA diffusion assay. Int Arch Occup Environ Health. 2012;85(7):807-818.

26. Palus J, Rydzynski K, Dziubaltowska E, Wyszynska K, Natarajan AT, Nilsson R. Genotoxic effects of occupational exposure to lead and cadmium. Mutat Res. 2003;540(1):19-28.

27. Steinmetz-Beck A, Szahidewicz-Krupska E, Beck B, Poreba R, Andrzejak R. Genotoxicity effect of chronic lead exposure assessed using the comet assay. Med Pr. 2005;56(4):295-302.

28. Jannuzzi AT, Alpertunga B. Evaluation of DNA damage and DNA repair capacity in occupationally lead-exposed workers. Toxicol Ind Health. Published online July 6, 2015. DOI: 10.1177/0748233715590919.

29. García-Lestón J, Roma-Torres J, Vilares M, et al. Biomonitoring of a population of Portuguese workers exposed to lead. Mutat Res. 2011;721:81-88. 